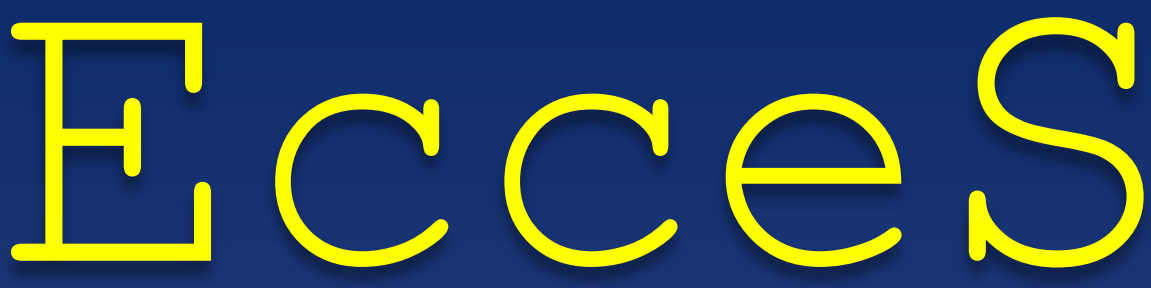

Economics, Social, and Development Studies

POSISI PENDUDUK KOTA MAKASSAR DALAM MENUNJANG

PEMBANGUNAN EKONOMI

Abdul Rahman dan Nur Rahmi Hamzah

EFISIENSI BELANJA PEMERINTAH DI SEKTOR PENDIDIKAN DAN KESEHATAN

DI PROVINSI SULAWESI SELATAN

Rapiuddin dan Bahrul Ulum Rusydi

STRUKTUR EKONOMI DAN POLA PEMBANGUNAN DAERAH

DI KAWASAN MAMMINASATA

Husni Mubarak dan Hasbiullah

PENGARUH PENGELUARAN PEMERINTAH DAN UPAH MINIMUM REGIONAL (UMR) TERHADAP TINGKAT PARTISIPASI ANGKATAN KERJA DI KOTA MAKASSAR

Ikhwan dan Siradjuddin

PENGARUH TENAGA KERJA DAN PENGELUARAN PEMERINTAH TERHADAP PERTUMBUHAN EKONOMI KOTA MAKASSAR

Irmayanti dan Aulia Rahman Bato

FAKTOR-FAKTOR YANG MEMENGARUHI PRODUKSI JAGUNG DI DESA TANAH TOWA KECAMATAN KAJANG KABUPATEN BULUKUMBA

Kamaluddin dan Andi Faisal Anwar

ANALISIS PENENTUAN SEKTOR UNGGULAN DAN PERUBAHAN STRUKTUR EKONOMI KABUPATEN JENEPONTO TAHUN 2011-2015

Syaripuddin dan Abdul Wahab 


\section{Ecces}

Economics, Social, and Development Studies

VOLUME 4 NOMOR 1 JUNI 2017

POSISI PENDUDUK KOTA MAKASSAR DALAM MENUNJANG

PEMBANGUNAN EKONOMI

Abdul Rahman dan Nur Rahmi Hamzah

EFISIENSI BELANJA PEMERINTAH DI SEKTOR PENDIDIKAN DAN KESEHATAN DI PROVINSI SULAWESI SELATAN

Rapiuddin dan Bahrul Ulum Rusydi

STRUKTUR EKONOMI DAN POLA PEMBANGUNAN DAERAH DI KAWASAN MAMMINASATA

Husni Mubarak dan Hasbiullah

PENGARUH PENGELUARAN PEMERINTAH DAN

UPAH MINIMUM REGIONAL (UMR) TERHADAP TINGKAT PARTISIPASI

ANGKATAN KERJA DI KOTA MAKASSAR

Ikhwan dan Siradjuddin

PENGARUH TENAGA KERJA DAN PENGELUARAN PEMERINTAH TERHADAP PERTUMBUHAN EKONOMI KOTA MAKASSAR

Irmayanti dan Aulia Rahman Bato

FAKTOR-FAKTOR YANG MEMENGARUHI PRODUKSI JAGUNG DI DESA TANAH TOWA KECAMATAN KAJANG KABUPATEN BULUKUMBA

Kamaluddin dan Andi Faisal Anwar

ANALISIS PENENTUAN SEKTOR UNGGULAN DAN PERUBAHAN STRUKTUR EKONOMI KABUPATEN JENEPONTO TAHUN 2011-2015

Syaripuddin dan Abdul Wahab 


\title{
PENGARUH TENAGA KERJ A DAN PENGELUARAN PEMERINTAH TERHADAP PERTUMBUHAN EKONOMI KOTA MAKASSAR
}

\author{
Irmayanti ${ }^{1}$ \\ Aulia Rahman Bato ${ }^{2}$
}

\begin{abstract}
ABSTRAK
Pertumbuhan Ekonomi adalah salah satu indikator yang sangat penting dalam pembagunan ekonomi suatu negara. Adapun faktor yang mempengaruhi pertumbuhan ekonomi diantaranya jumlah tenaga kerja. Selain itu, pemerintah juga memiliki wewenang dalam mengatur dan mengawasi pembangunan ekonmi suatu daerah. Penelitian ini bertujuan untuk menjelaskan bagaimana pengaruh tenaga kerja dan pengeluaran pemerintah terhadap pertumbuhan ekonomi kota makassar. Adapun manfaat penelitian ini yaitu diharapkan dapat memberikan masukan yang berguna bagi pemerintah, masyarakat ataupun mahasiswa.

Penelitian ini merupakan jenis penelitian kepustakaan yang bersifat deskriftif kuantitatif dengan model analisis regresi linear berganda. Data yang digunakan adalah data sekunder dari tahun 2005 sampai dengan tahun 2014 yang diambil dari Badan Pusat Statistik (BPS) kota makassar dan literatur-literatur yang berhubungan dengan penelitian ini.

Hasil analisis menunjukkan bahwa variabel tenaga kerja dan pengeluaran pemerintah berpengaruh signifikan dan berhubungan positif terhadap pertumbuhan ekonomi kota makassar. Secara parsial, tenaga kerja berpengaruh signifikan dan berhubungan positif terhadap pertumbuhan ekonomi kota makassar. Pengeluaran pemerintah berpengaruh signifikan dan berhubungan positif terhadap pertumbuhan ekonomi kota makassar. Sehingga penulis menyarankan kepada pemerintah kota makassar untuk meningkatkan jumlah tenaga kerja dan pengeluaran pemerintah baik dari sisi pengeluaran rutin maupun pembangunan untuk dapat meningkatkan pertumbuhan ekonomi.
\end{abstract}

Kata kunci: Tenaga Kerja, Pengeluaran Pemerintah, Pertumbuhan Ekonomi

\section{PENDAHULUAN}

Pada hakikatnya pembangunan ekonomi adalah serangkaian usaha dan kebijaksanaan yang bertujuan untuk meningkatkan taraf hidup masyarakat, memperluas lapangan kerja, meratakan pembagian pendapatan masyarakat, meningkatkan hubungan regional, dan melalui pergeseran struktur kegiatan ekonomi dari sektor prime kesektor sekunder. Pembangunan juga meliputi perubahan dalam tingkat pertumbuhan ekonomi,pengurangan ketimpangan pendapatan dan pemberantasan kemiskinan.

1 Universitas Islam Negeri Alauddin Makassar

2 Universitas Islam Negeri Alauddin Makassar 
Salah satu indikator untuk mengatur keberhasilan pembangunan dalam suatu negara adalah pertumbuhan ekonomi. Pertumbuhan ekonomi adalah sebagian dari perkembangan kesejahtraan masyarakat yang di ukur dengan besarnya pertumbuhan Produk Domestik Regional Bruto. Suatu masyarakat di pandang mengalami suatu pertumbuhan dalam kemakmuran apabila, pendapatan perkapita menurut harga atau pendapatan terus menerus bertambah dan laju pertumbuhan ekonomi semakin meningkat. Salah satu kota yang akan dilihat pertumbuhan ekonominya yaitu kota makassar.

Tabel 1. Data Perkembangan dan Pertumbuhan Ekonomi Kota Makassar

Periode 2004-2008

\begin{tabular}{|c|c|c|c|c|}
\hline TAHUN & $\begin{array}{c}\text { PDRB ADH } \\
\text { BERLAKU }\end{array}$ & PERKEMBANGAN & $\begin{array}{c}\text { PDRB ADH } \\
\text { KONSTAN }\end{array}$ & $\begin{array}{c}\text { PERTUMB UHAN } \\
\text { EKONOMI (\%) }\end{array}$ \\
\hline 2004 & $13.127 .238,54$ & 17,93 & $9.785 .333,89$ & 10,17 \\
\hline 2005 & $15.744 .193,91$ & 19,94 & $10.492 .540,67$ & 7,16 \\
\hline 2006 & $18.165 .876,32$ & 15,38 & $11.341 .848,21$ & 8,09 \\
\hline 2007 & $20.794 .721,30$ & 14,47 & $12.261 .538,92$ & 8,11 \\
\hline 2008 & $26.068 .221,49$ & 25,06 & $13.561 .827,18$ & 10,52 \\
\hline
\end{tabular}

Sumber :Badan Pusat Statistik Kota Makassar, 2017

Selain itu, tenaga kerja dan pengeluaran pemerintah merupakan faktor yang berpengaruh terhadap pertumbuhan ekonomi kota makassar. Dimana tenaga kerja merupakan sumber daya menusia yang merupakan roda pembagunan dalam perekonomian. Pengeluaran pemerintah pun demikian, karena belanja pemerintah sangat berperan dalam peningktan pertumbuhan ekonomi yang tercermin dalam APBD.

Berdasarkan hal-hal yang dikemukakan diatas, penulis mencoba untuk membahas masalah pertumbuhan ekonomi kota makassar dalam hubungannya terhadap tenaga kerja dan pengeluaran pemerintah dengan judul Pengaruh Tenaga Kerja dan Pengeluaran Pemerintah terhadap Pertumbuhan Ekonomi Kota Makassar.

\section{TINJ AUAN PUSTAKA}

\section{Konsep Tenaga Kerja}

Dalam ilmu ekonomi yang dimaksud dengan tenaga kerja (labour) bukanlah semata mata kekuatan manusia untuk mencangkul, menggarap, 
bertukang dan segala kegiatan fisik lainya. Hal yang di maksud disini human resources (sumber daya manusia). Tenaga kerja didefinisikan sebagai penduduk berumur 10 tahun atau lebih yang bekerja, mencari pekerjaan, dan sedang melakukan kegitatan lain, seperti sekolah maupu mengurus rumah tangga dan penerima pendapatan. Menurut BPS penduduk berumur 10 keatas terbagi sebagai tenaga kerja.

Sedangkan menurut Mankiw membedakan tenaga kerja (labour) menjadi dua yaitu tenaga kerja berpendidikan (educated) dan tidak berpendidikan (uneducated). Disini tenaga kerja berpendidikan (educated labour) diindikasikan dengan proporsi angkatan kerja yang memiliki tingkat pendidikan lanjutan (proportion of the labour force with secondary education).

\section{Pengeluaran Pemerintah}

Peran pemerintah selalu meningkat dalam semua system perekonomian. Semakin meningkatnya peran peran pemerintah dapat di lihat dari semakin besarnya pengeluaran pemerintah dalam proposinya terhadap penghasilan atau pendapatan nasional. Pengeluaran pemerintah dalam arti rill dapat di pakai sebagai indicator besarnya kegiatan pemerintah yang di biayai oleh pengeluaran pemerintah.

Teori pembagunan dan pengeluaran pemerintah di kembangkan oleh Rostow dan Musgrave yang menghubungkan pengeluaran pemerintah dengan tahap-tahap pembangunan ekonomi yang di bedakan antara tahap awal, tahap menengah, dan tahap lanjut. (1) tahap awal, pada tahap awal perkembangan ekonomi presentase investasi besar, sebab pemerintah harus menyediakan prasarana, seperti pendidikan, kesehatan, prasarana transportasi dan sebagainya. (2) tahap menengah, investasi pemerintah tetap di perlukan untuk meningkatkan pertumbuhan ekonomi agar dapat tinggal landas, namun peranan investasi swasta sudah semakin membesar. (3) tahap lanjut, pembagunan ekonomi dan aktivitas pemerintah beralih dari penyediaan prasarana ke pengeluaran - pengeluaran untuk aktivitas social seperti program kesejahtraan hari tua dan program pelayanan kesehatan masyarakat.

Selain itu, Teori Hukum Wagner menyatakan bahwa dalam suatu perekonomian, apabila pendapatan perkapita meningkat, secara relatif pengeluaran pemerintah pun akan meningkat. Menurut Wagner mengapa peranan 
pemerintah semakin besar, disebabkan karena pemerintah harus mengatur hubungan yang timbul dalam masyarakat, hukum, pendidikan, rekreasi kebudayaan dan sebagainya.

\section{Teori Pertumbuhan Ekonomi}

Pertumbuhan Ekonomi adalah salah satu indicator yang sangat penting dalam melakukan analisis tentang pembangunan ekonomi yang terjadi pada suatu Negara. Pertumbuhan ekonomi menunjukkan sejauh mana aktivitas perekonomian akan menghasilkan tambahan pendapatan masyarakat pada suatu priode tertentu. Pertumbuhan ekonomi terjadi apabila ada kecenderungan output per kapita untuk naik yang bersumber dari kekuatan yang berada dalam perekonomian itu sendiri, bukan berasal dari luar atau bersifat sementara.

Pertumbuhan ekonomi dapat di artikan juga sebagai proses kenaikan kapasitas produksi suatu perekonomian yang diwujudkan dalam bentuk kenaikan pendapatan nasional. Indikator yang digunakan untuk mengukur pertumbuhan ekonomi adalah tingkat pertumbuhan Produk Domestik Bruto (PDB).

Teori pertumbuhan dapat dikelompokkan kedalam suatu perekonomian, yaitu melihat bagaimana perekonomian berkembang atau berubah dari waktu kewaktu. Yaitu:

1. Teori Pertumbuhan Ekonomi Klasik

2. Teori Pertumbuhan Ekonomi Neo Klasik

\section{Hubungan Antar Variabel}

Pertumbuhan penduduk dan pertumbuhan tenaga kerja secara tradisional dianggap sebagai salah satu factor positif yang memacu pertumbuhan ekonomi. Jumlah tenaga kerja yang lebih besar berarti akan menambah tingkat produksi, sedangkan pertumbuhan penduduk yang lebih besar berarti ukuran pasar domestiknya lebih besar. Sedangkan Pengeluaran pemerintah (goverment expenditure) adalah bagian dari kebijakan fiskal yakni suatu tindakan pemerintah untuk mengatur jalannya perekonomian dengan cara menentukan besarnya penerimaan dan pengeluaran pemerintah tiap tahunnya yang tercermin dalam dokumen APBN untuk nasional dan APBD untuk daerah/regional. Tujuan dari kebijakan fiskal ini adalah dalam rangka menstabilkan harga, tingkat output maupun kesempatan kerja dan memacu pertumbuhan ekonomi. 


\section{METODE PENELITIAN}

\section{Pendekatan Penelitian dan Sumber Data}

Pengumpulan data yang dilakukan melalui membaca data-data, laporan, teori atau jurnal yang mempunyai hubungan dengan permasalahan yang akan dibahas.

Jenis data yang digunakan adalah data sekunder (time series data). Data ini berupa data pertumbuhan ekonomi di kota Makassar sesuai dengan pembatasan periode dalam penelitian ini tahun 2005 - 2014.

Sumber data yang digunakan dalam penelitian ini berasal dari Badan pusat statistik Provinsi Sulawesi Selatan, Badan Pusat Statistik Kota Makassar dan website Bank Indonesia, Dinas Tenaga Kerja Kota Makassar, serta berbagai situs dan website yang berhubungan dengan penelitian.

\section{Teknik Analisis Data}

Model analisis yang akan digunakan dalam penelitian ini adalah model analisis inferensial, yaitu analisis regresi berganda untuk mengetahui Data Tenaga kerja dan data pengeluaran pemerintah terhadap Pertumbuhan Ekonomi yang dinyatakan dalam bentuk fungsi sebagai berikut:

$$
Y=f(X 1, X 2)
$$

Secara eksplisit dapat dinyatakan dalam fungsi Cobb-Douglas berikut:

$$
Y=\beta_{0}+\beta_{1} X_{1}+\beta_{2} X_{2}+\mu
$$

Untuk mengestimasi koefisien regresi, mengadakan transformasi ke bentuk linear dengan menggunakan logaritma natural (In) guna menghitung nilai elastisitas dari masing-masing variable bebas terhadap variable terikat kedalam model sehingga diperoleh persamaan sebagai berikut:

$$
\operatorname{Ln} Y=\operatorname{Ln} \beta_{0}+\beta_{1} \operatorname{Ln} X_{1}+\beta_{2} \operatorname{Ln} X_{2}+\mu
$$

Dimana:

$$
\begin{array}{ll}
\mathrm{Y} & =\text { Pertumbuhan Ekonomi } \\
\mathrm{X}_{1} & =\text { Tenaga Kerja } \\
\mathrm{X}_{2} & =\text { Pengeluaran Pemerintah } \\
\beta_{0} & =\text { Konstanta } \\
\beta_{1}-\beta_{2} & =\text { Parameter } \\
\mu & =\text { Error term }
\end{array}
$$


Sebelum analisis regeresi digunakan, maka terlebih dahulu akan dilakukan uji asumsi klasik untuk selanjutnya akan dilakukan uji hipotesis dengan bantuan program SPSS versi 21. Analisis yang digunakan dalam penelitian ini adalah Analisis Koefesien Determinasi (R2), Uji F, Uji t.

\section{HASIL DAN PEMBAHASAN}

\section{Analisis Hasil Regresi}

\begin{tabular}{|c|c|c|c|c|c|}
\hline \multicolumn{2}{|l|}{ Variabel } & Coefisien & Std. Error & t - Statistil & Prob \\
\hline \multicolumn{2}{|l|}{ Constant } & -8.554 & 4.985 & 1.716 & 0.130 \\
\hline \multicolumn{2}{|l|}{ Tenaga kerja $\left(\mathrm{X}_{1}\right)$} & 1.429 & 0.405 & 3.523 & 0.010 \\
\hline \multicolumn{2}{|c|}{ Pengeluaran pemerintah $\left(\mathrm{X}_{2}\right)$} & 0.294 & 0.070 & 4.225 & 0.004 \\
\hline R - Squared & 0.868 & \multicolumn{3}{|c|}{ S.E Regression } & 0.11103 \\
\hline $\mathrm{R}$ & 0.932 & & \multicolumn{2}{|c|}{ F - Statistik } & 23.083 \\
\hline Adjused R - Squared & 0.831 & & \multicolumn{2}{|c|}{ Prob. F - Statistik } & 0.001 \\
\hline
\end{tabular}

Hasil penelitian pada tabel tersebut menjelaskan bahwa secara statistik pengeluaran pemerintah berpengaruh signifikan (nilai sig $.001<$ taraf signifikansi $5 \%$ ) dan berpengaruh positif (nilai koefisien estimasi bernilai positif 0.599 ) terhadap TPAK. Sementara upah minimum regional (UMR) berpengaruh signifikan (nilai sig $.049<$ taraf signifikansi 5\%) dan berpengaruh negatif (nilai koefisien estimasi bernilai negatif -0.177 ) terhadap TPAK.

Nilai R-Squared menunjukkan bahwa variabel bebas yaitu pengeluaran pemerintah dan upah minimum regional memberikan kontribusi sebesar $87.3 \%$ terhadap perubahan dari variabel terikat yaitu tingkat pertisipasi angkatan kerja. Sedangkan sisanya sebesar $12.7 \%$ dipengaruhi oleh variabel lain diluar penelitian ini.

Pengeluaran pemerintah memiliki pengaruh signifikan dan berhubungan positif $(0,001>0,05)$ terhadap tingkat partisipasi angkatan kerja. Selanjutnya koefisien regresinya yaitu sebesar 0,599 menunjukkan bahwa setiap penambahan pengeluaran pemerintah $1 \%$ maka akan meningkatkan tingkat partisipasi angkatan kerja sebesar 0,6\%. Dengan melihat hasil analisis menunjukkan bahwa hubungan antara pengeluaran pemerintah terhadap tingkat partisipasi angkatan kerja memiliki hubungan yang positif dan berpengaruh signifikan. Hal ini disebabkan pengeluaran pemerintah di Kota Makassar cenderung berorientasi 
pada belanja modal. Sehingga tingginya pengeluaran pemerintah memberikan dampak yang besar terhadap pembangunan ekonomi di Kota Makassar. Hal ini berdampak pada meningkatnya angka tingkat partisipasi angkatan kerja.

Upah minimum regional memiliki pengaruh signifikan dan berhubungan negatif $(0,049>0,05)$ terhadap tingkat partisipasi angkatan kerja. Selanjutnya koefisien regresinya yaitu sebesar $-0,117$ akan menurunkan tingkat partisipasi angkatan kerja sebesar 0,12\%. Dengan melihat hasil analisis menunjukkan bahwa hubungan antara upah minimum regional terhadap tingkat partisipasi angkatan kerja memiliki hubungan yang negatif dan berpengaruh signifikan. Hal ini disebabkan oleh beberpa indikator diantaranya berkurangnya jumlah ankatan kerja pada saat terjadinya peningkatan upah, sepertinya yang terjadi pada tahun 2007 ke tahun 2008 dimana terjadi peningkatan upah sementara tingkat partisipasi angkatan kerjanya menurun. Atau dari tahun 2011 ke tahun 2012 dengan upah Rp 1.100.000,00 menjadi Rp. 1.200.000,00 ternyata menurunkan TPAK dari $62 \%$ menjadi $57,94 \%$. Pemberian upah yang tinggi diharapkan perusahaan dapat lebih meningkatkan produktifitas pekerjanya, sehingga tidak diperlukan lg penambahan karyawan. Dengan kata lain tidak adanya peningkatan jumlah angkatan kerja pada waktu atau periode tersebut.

\section{Pengujian Simultan (Uji F)}

Uji simultan ini dilakukan untuk menguji pengaruh secara bersama-sama variabel bebas terhadap variabel terikat. Berdasarkan pengujian statistik pada tabel 4diperoleh $F_{\text {hitung }}>F_{\text {tabel }}(23.083>4,74)$ dengan tingkat signifikan sebesar 0,010 karena lebih kecil dari $0,05(0,010<0,05)$, maka $\mathrm{H}_{\mathrm{a}}$ diterima dan $\mathrm{H}_{\mathrm{o}}$ ditolak. Hal ini berarti bahwa secara simultan atau bersama-sama variabel tenaga kerja $\left(X_{1}\right)$ dan pengeluaran pemerintah $\left(X_{2}\right)$ berpengaruh terhadap pertumbuhan ekonomi di Kota Makassar (Y).

\section{Pengujian Parsial (Uji t)}

Uji parsial atau uji t bertujuan untuk mengetahui pengaruh masing-masing variabel bebas terhadap variabel terikat. Proses pengujian dilakukan dengan melihat pada tabel uji parsial dengan memperhatikan kolom signifikansi dan nilai $t_{\text {tabel }}$ dengan thitung. 


\section{Pengaruh Tenaga Kerja terhadap Pertumbuhan Ekonomi di Kota Makassar}

Variabel tenaga kerja mempunyai angka signifikan sebesar 0,010 karena nilai signifikan lebih besar dari 0,05 $(0,010<0,05)$. Hal ini ditunjukkan dengan nilai $t_{\text {hitung }}>t_{\text {tabel }}(3,523<2,365)$ dari hasil tersebut dapat disimpulkan bahwa Ha diterima dan Ho ditolak. Sehingga dapat dikatakan bahwa tenaga kerja berpengaruh signifikan terhadap pertumbuhan ekonomi di Kota Makassar.

\section{Pengaruh Pengeluaran Pemerintah terhadap Pertumbuhan Ekonomi di Kota Makassar}

Variabel pengeluaran pemerintah mempunyai angka signifikan sebesar 0,004 karena nilai signifikan lebih kecil dari 0,05 $(0,004<0,05)$. Hal ini ditunjukkan dengan nilai $t_{\text {hitung }}>t_{\text {tabel }}(4,225>2,365)$ dari hasil tersebut dapat disimpulkan bahwa Ha diterima dan Ho ditolak. Sehingga dapat dikatakan bahwa pengeluaran pemerintah berpengaruh signifikan terhadap pertumbuhan ekonomi di Kota Makassar.

\section{Diskusi Hasil}

Berdasarkan hasil pengujian uji parsial (uji t) hipotesis $X_{1}$, maka hasil perhitungan yang didapat adalah probabilitas signifikansi yang lebih besar dari taraf signifikansi yaitu yaitu $0,010>0,05$, menyatakan tenaga kerja berpengaruh signifikan dan berhubungan positif terhadap pertumbuhan ekonomi di kota makassar. Selain itu, $t_{\text {hitung }}=0,010$ sedangkan $t_{\text {tabel }}=0,05$ sehingga $t_{\text {hitung }}>t_{\text {tabel }}$ $(0,010>0,05)$. Dari hasil tersebut dapat di simpulkan bahwa $\mathrm{H}_{\mathrm{o}}$ diterima dan $\mathrm{H}_{\mathrm{a}}$ ditolak. Sehingga dikatakan bahwa tenaga kerja signifikan dan berhubungan positif terhadap pertumbuhan ekonomi dikota Makassar.

Dalam penelitian ini menunjukkan bahwa semakin tinggi jumlah tenaga kerja di kota Makassar maka akan meningkatkan pertumbuhan ekonomi, dapat dilihat pada tabel yang menunjukkan jumlah tenaga kerja dikota Makassar mengalami peningkatan setiap tahunnya yang cukup signifikan. Hal ini membuktikan bahwa tingginya jumlah tenaga kerja dapat mempengaruhi pertumbuhan ekonomi di kota Makassar.

Sesuai dengan penelitian yang dilakukan oleh Avanda Fahri Athari (2009), yang menyatakan bahwa tenaga kerja merupakan salah satu faktor yang menentukan laju pertumbuhan ekonomi, yaitu semakin bertambah jumlah tenaga 
kerja semakin pertambah pula tingkat petumbuhan ekonomi. Hal ini sesuai dengan teori yang digunakan yaitu teori yang di kemukakan oleh Todaro bahwa pertumbuhan penduduk dan pertumbuhan tenaga kerja secara tradisional dianggap sebagai salah satu faktor positif yang memacu pertumbuhan ekonomi. Jumlah tenaga kerja yang lebih besar berarti akan menambah tingkat produksi, sedangkan pertumbuhan penduduk yang benar-benar cepat akan memberikan dampak positif dari pembagunan ekonomi.

Dan diperkuat oleh penelitian yang di lakukan Dwi Suryanto (2011), menyimpulkan bahwa Tenaga kerja tidak saja penting dari sudut kuantitas, tetapi yang tidak kalah penting lagi dari kualitasnya. Peningkatan kualitas tenaga kerja dapat dilakukan melalui pendidikan formal maupun pendidikan non formal, dan dapat saja diselenggarakan oleh pemerintah dan swasta. Ini merupakan faktor yang menentukan pertumbuhan suatu daerah, dimana jumlah tenaga kerja akan berpengaruh positif terhadap pertumbuhan ekonomi.

Berdasarkan hasil pengujian uji parsial (uji t) hipotesis $\mathrm{X}_{2}$ diperoleh bahwa pengeluaran pemerintah memiliki pengaruh positif dan signifikan terhadap pertumbuhan ekonomi di kota Makassar. Hal ini dapat dilihat dari tabel 4.7 bahwa pengeluaran pemerintah (belanja modal) berpengaruh signifikan dan berhubungan positif $(0,004>0,05)$ terhadap pertumbuhan ekonomi. Dalam konsep makro pengeluaran pemerintah akan meningkatkan perekonomian nasional. Pengeluaran pemerintah yang mendorong perekonomian ini tentunya dengan asumsi bahwa pengeluaran pemerintah digunakan sepenuhnya untuk kegiatankegiatan ekonomi atau yang memberikan dorongan bagi perkembangan bagi kegiatan ekonomi. Jadi apabila pengeluaran pemerintah meningkat maka akan terjadi pertumbuhan ekonomi.

Menurut penelitian yang dilakukan oleh Dwi Suryanto (2011), yang meneliti pertumbuhan ekonomi di SUBOSUKAWONOSRATEN tahun 2004-2008 menyimpulkan pengeluran pemerintah merupakan investasi yang dihasilkan berupa sarana dan prasarana publik yang tidak disediakan swasta namun diharapkan mengalokasikan belanja aparatur daerah (yang memberi dampak secara tidak langsung terhadap pembangunan) dengan belanja modal (yang memberi dampak langsung terhadap pembangunan). Dari kesimpulan semuanya jurnal menyimpulkan bahwa pengeluaran pemerintah secara signifikan berpengaruh yang positif terhadap pertumbuhan ekonomi. 
Belanja modal berfungsi untuk membiayai pelayanan atau program pembangunan tertentu. terhadap hubungan antara perkembangan belanja pemerintah dengan tahap-tahap pembangunan ekonomi dibedakan antara tahap awal, tahap menengah, dan tahap lanjut.

Menurut teori Wegner menyatakan bahwa dalam suatu perekonomian, apabila pendapatan perakapita meningkat secara relative pengeluaran pemerintah pun akan meningkat.

\section{KESIMPULAN}

Berdasarkan hasil penelitian yang dilakukan, maka dapat diambil kesimpulan sebagai berikut:

1. Berdasarkan hasil analisis dan pembahasan bahwa variabel tenaga kerja dan pengeluaran pemerintah berpengaruh signifikan dan berhubungan positif terhadap pertumbuhan ekonomi dikota Makassar (2005-2014).

2. Tenaga kerja berpengaruh signifikan dan berhubungan positif terhadapa pertumbuhan ekonomi kota Makassar.

3. Pengeluaran pemerintah berpengaruh signifikan dan berhubungan positif terhadap pertumbuhan ekonomi kota Makassar.

\section{DAFTAR PUSTAKA}

Anis, Ananta. 1990. Ekonomi Sumber Daya Manusia. Jakarta:Lembaga Demografi Universitas Indonesia Fakultas Ekonomi.

Arsyad, Lincolin. 2009. Pengatur Perencanaan Pembangunan Ekonomi Daerah E disi Kedua.BPFE-YOGYAKARTA.

Bakri, Zaenab dan Manning, Chris. 1984. Angkatan Kerja Di Indonesia. Partisipasi, Kesempatan dan Pengangguran.Jakarta : CV Rajawali.

Dumairy. 1996. Perekonomian Indonesia. Jakarta:Erlangga.

Indriantoro. 1999. Metodologi untuk Aplikasi dan Bisnis.Yogyakarta: BPFEYOGYAKARTA.

Jhingan, M.L. 2008. Ekonomi Pembangunan dan Perencanaan. Jakarta:PT. RajaGrafindo.

Mangkoesoebroto, Guritno. 2013. Ekonomi Publik Edisi Ketiga.Yogyakarta : BPFE-YOGYAKARTA.

Mankiw, N Gregory.Makroekonomi Edisi Keenam.Jakarta : Erlangga.

Mubyarto. 1997. Ekonomi Rakyat Program IDT dan Demokrasi Ekonomi Indonesia. Yogyakarta:Aditya Media Publication. 
Rahayu, Ani Sri. 2010. Pengantar Kebijakan Fiskal. Jakarta : PT Bumi Aksara.

Samuelson dan Nordhaus. 1996. Makroekonomi (terjemahan),Edisi Keempat. Jakarta:Erlangga.

Simanjuntak, Payman. 2001.Pengantar Ekonomi Sumber Daya Manusia. Jakarta : Lembaga Penerbit FE-UI.

Soeparmoko. 1994. Pengantar Ekonometrika Makro.Yogyakarta:BPFE.

Sukirno, Sadono. 2011. Makroekonomi Teori Pengantar. Jakarta : PT Raja Grafindo, Edisi Ketiga.

Sumarsono, Sony. 2003. Ekonomi Manajemen Sumber Daya Manusia dan Ketenagakerjaan. Yogyakarta: Graha IImu.

Suryadi, Asep. 2003. Minimum Wage Policy and Its Impact on Employment in the Urban Formal Sector. BIES.

Todaro, Michael P. Dan Smith, Stephen C. 2003. Pembangunan Ekonomi di Dunia Ketiga, edisi Kedelapan. Jakarta: Erlangga.

Todaro. Michael p. (2000). Pembangunan ekonomi di dunia ketiga, edisi ketujuh terjemahan haris munandar. Jakarta: Erlangga. 


\section{E C C E S}

Economics, Social, and evelopment Studies

Jurusan IImu Ekonomi

Fakultas Ekonomi dan Bisnis Islam UIN Alauddin

Kampus II Jl. SIt Alauddin No.36 Samata Sungguminasa-Gowa Telp (424835)

Email: ecces@uin-alauddin.ac.id

Aturan penulisan Jurnal IImu Ekonomi Fakultas Ekonomi dan Bisnis Islam UIN Alauddin Makassar adalah sebagai berikut:

1. Artikel harus berupa tulisan asli, merupakan hasil penelitian maupun kajian dalam bidang ekonomi terapan dan belum pernah dipublikasikan di media manapun serta bebas dari unsur-unsur plagiarisme.

2. Artikel ditulis dalam Bahasa Indonesia dengan memenuhi kaidah EYD Bahasa Indonesia.

3. Sistematika penulisan:

a. Bagian awal: judul, nama penulis (dituliskan lengkap tanpa gelar), abstrak yang tidak lebih dari 300 kata dan diketik dengan satu spasi yang berisi latar belakang, tujuan, metodologi, dan hasil penelitian.

b. Bagian utama: pendahuluan, tinjauan teoritis dan pustaka, metode penelitian, hasil dan pembahasan, serta kesimpulan.

c. Bagian akhir: daftar pustaka, dan lampiran.

4. Judul artikel ditulis dengan menggunakan huruf kapital.

5. Teknik penulisan:

a. Alinea baru dimulai pada ketikan kelima pada batas tepi kiri. Antar alinea tidak diberi tambahan spasi.

b. Penggunaan kata asing ditulis dengan menggunakan huruf miring (italic).

c. Batas pengetikan: tepi kiri tiga $\mathrm{cm}$, tepi kanan dua $\mathrm{cm}$, tepi atas tiga $\mathrm{cm}$, dan tepi bawah dua $\mathrm{cm}$.

d. Tabel, gambar, dan ilustrasi lainnya diberikan judul, nomor, dan sumber yang jelas.

e. Sumber pustaka ditulis nama-tahun (nama belakang penulis, tahun penerbitan). Nama penulis harus tepat sama dengan yang tercantum dalam daftar pustaka.

6. Naskah diketik dengan MS Word, spasi satu, ukuran font 11, huruf Arial, dengan panjang minimum-maksimum 15-20 halaman (A4).

7. Tulisan harus dikirim paling lambat 1 bulan sebelum penerbitan jurnal ke email jurnal Ecces atau diserahkan langsung ke tim pengelola dalam bentuk CD.

8. Jurnal Ecces terbit 2 kali dalam setahun, yaitu Juni dan Desember.

9. Email jurnal Ecces: jurnalecces@gmail.com 


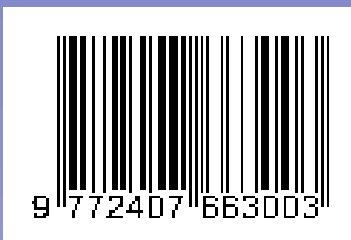

